\title{
Environmental Impact Assessment of Transport Infrastructure Projects in Sri Lanka: Way Forward
}

\author{
I.M. Gamalath ${ }^{1 *}$, H.L.K. Perera ${ }^{1}$ and J.M.S.J. Bandara ${ }^{1}$ \\ ${ }^{1}$ Department of Civil Engineering, University of Moratuwa, Sri Lanka
}

Date Received: 18-12-2013 Date Accepted: 28-04-2014

\begin{abstract}
Environmental Impact Assessment (EIA) was established to manage impacts on environment due to development projects and to enhance environmental quality where possible. However, recent incidents concerning several projects have aroused the question, "Are we utilising EIA effectively?" Therefore this study was carried out to find the possible methods of improving the quality and effectiveness of EIA. Literature regarding EIA process in Sri Lanka as well as in international context was reviewed together with several past EIA reports related to civil engineering infrastructure projects to identify possible improvements. Identified problems can be categorised mainly in to two; problems in established EIA framework and methodologies adopted in impact assessment. Main problems identified with regard to EIA framework are lack of environmental, social protection policies and proper post monitoring plan. The problems with regard to assessment process are lack of incorporating cumulative effects and sustainability concepts in evaluation.

In order to address these issues, legislature should be improved and they should focus on allocating proper weight to the EIA findings in the decision process. In impact assessment, the product of magnitude of the impact and the duration of impact should be taken into account rather than just focusing on the magnitude. Further analysing impacts should focus more on concepts of environmental resources and limitations rather than narrow impacts of the project. In addition to the project based EIA process, Strategic Environmental Assessment (SEA) can be practised to overcome the weaknesses of the reactive nature of EIA and to direct development in the right direction.
\end{abstract}

Keywords: assessment methodology, environmental impact assessment, impact on climate, sustainability concepts

\section{Introduction}

Environmental issues are receiving high priority in the development agenda at present as humans are now suffering from neglecting those in the early stages of development. Climate change and resource degradation are some of the major impacts, the world faces today. Learning from past, Environmental Impact Assessment (EIA) was established to manage impacts on environment due to development projects and to enhance the environmental quality where possible.

\footnotetext{
* Correspondence: imgamalath@gmail.com

Tel: +947192588348

ISSN 2235-9370 Print/ISSN 2235-9362 Online (C) University of Sri Jayewardenepura
} 
However, recent incidents concerning several projects have aroused the question, "Are we utilising EIA effectively?" Public question the validity of several EIA as those projects have caused considerable negative impacts both at local and regional levels. They question not only the content of the reports, but the priority given to EIA findings in the decision making process and the conflict of interest of institution involved in the EIA process (Jayawardana, 2012; Kannangara, 2013).

Therefore this study was conducted to identify the possible methods of improving the quality of EIA and enhancing its usefulness in the decision making process. Literature regarding the Environmental Assessment (EA) and a number of EIA reports were reviewed together with interviews with professionals who involved in evaluations to identify the current weaknesses and possible improvements.

All these fundamental questions regarding EIA arise because project implementers see the EIA report just as a rubber stamp that is required to initiate their projects. Hence many of the issues faced today can be solved by emphasising the advantages of the EIA to the project proponent and the implementers while providing proper guidelines to follow. This paper discusses such improvements needed in the guidelines and methods needed to be adopted to enhance the effectiveness of the EIA process and reap its maximum benefits.

\subsection{EIA Inception and Practice in Sri Lanka}

\section{History}

EIA is a widely practiced assessment or appraisal tool, which is currently used by both develop and developing countries. EIA was first established in the United States in 1969 with the National Environmental Policy Act. This was a response of the US congress to the increasing environmental damage due to the rapid development occurred during that time (Jay et al., 2007).

Soon after its inception, it was adopted by many developed nations as all of them were facing serious environmental consequences due to industrialization (Lee, 1983). The agreement of European Union (EU) members in 1980s to make EIA mandatory in development projects is an example (Commission of the European Communities, 1985). In Asian context, Japan, Thailand and Philippines are now have long established procedures while the South Asian countries exist at varying levels (Hennayake, 1997).

\section{EIA in Sri Lanka}

The National Environmental Act (NEA) No. 47 was enacted in 1980 in Sri Lanka. This was followed by amendments in 1988 and 2000; Act No. 56 of 1988 and Act No. 53 of 2,000 (Central Environmental Authority, 2006). Further, Coast Conservation Act (CCA), No. 57 of 1981 covers the projects coming under the cost conservation department which lies within $300 \mathrm{~m}$ from shore line (Central Environmental Authority, 1998).

The EIA process is mandated only for prescribed projects. Standard procedures and prescribed list were first based on Gazettes Extra-Ordinary No. 772/22 of $24^{\text {th }}$ June 1993. Later it was modified by Gazettes Extra-Ordinary No. 859/14 of $23^{\text {rd }}$ February 1995, No. $978 / 13$ of $4^{\text {th }}$ June 1997 , No. $1104 / 22$ of $05^{\text {th }}$ November 1999 , No. $1108 / 1$ of $29^{\text {th }}$ November 1999, No. $1159 / 22$ of $22^{\text {nd }}$ November 2000 and No. 1373/6 of $29^{\text {th }}$ December 2004 (Central Environmental Authority, 2006). Further 138 industries/activities are mandated under Gazette Notification No. $1533 / 16$ of $25^{\text {th }}$ January 2008 to obtain Environmental Protection License to maintain their activities (Central Environmental Authority, 2009). 
The study helped to identify various deficiencies in the EIA process in Sri Lankan context. Problems start from the initial stage itself. Since the Project Proponents' (PP) desire is to commence the projects as early as possible they try to skip the EIA process (Wijesekara, 1999). PPs manipulate the provisions in the law such as prescribed list. They make initial project proposals just under the threshold limits and expand them soon after the initial construction is completed (Zubair, 2001).

Since the timing of the EIA process has not been clearly defined in legislation, EIA process (Fig. 1) is usually conducted after the selection of alternatives. Environmental impacts are not thoroughly considered in this alternative selection (De Silva, Pers. Comm.). Therefore EIA reports are biased to the pre-selected alternatives. Unfeasible alternatives are commonly used in the evaluation process to justify the preferred alternative (Zubair, 2001). Most of the time, not even no-option alternative is considered in the evaluation (Bandara, 2001).

Insufficient environmental and other important data such as hydrological and geological data have hindered the evaluation process. This has led the evaluators to use unreliable secondary data in their evaluation process (De Silva, Pers. Comm.). Further, this has led to fabrication of data or sometimes to bypass the EIA process by certain project proponents (Zubair, 2001). Use of insufficient data to evaluate impacts is common especially in the case of transport infrastructure development projects as the impacted area is wide spread; where collecting such vast data is difficult within the limited time and other resources provided for the study.

Though there are several guidelines for the EIA process, no proper guidelines are given for evaluation or the content of the EIA report in Sri Lanka. Hence most of the time EIA reports just present a list of identified possible impacts, mostly without their expected magnitude and the extent (Bandara, 2001; De Silva, Pers. Comm.). Further, these impacts mainly focus on narrow, short-term and immediate impacts of individual project. Impact evaluation has usually neglected the reduction of limited environmental resources, projects contribution to climate change mitigation and adaptation strategies and cumulative impacts (Folkeson et al., 2013). The trend of identify only the impacts, not their magnitude has led to preparation of generic EIA reports rather than site specific evaluation reports. Further this makes it impossible to conduct a cost benefit analysis including costs for these mitigation measures. In addition lack of co-ordination among EIA group members have led to conflicting remarks and unnecessary or repetition of information in reports (Bandara, 2001). This is also due to the fact that reports only contains descriptive format.

Many countries, especially developing countries, lack of legal framework and policies for environmental and social protection. This has given the opportunity to PP and the evaluators to neglect some undesirable impacts and not to take necessary mitigate measures in practice (Lee \& George, 2000; Jay et al., 2007).

Lack of public participation in the EIA process is another issue that has been identified by past researchers (Caron, 2003). Even though there are regulations stipulated allowing public participation ( 30 days period), in most of the cases public participation in the process is not taking place at satisfactory level due to lack of understanding of the importance of the EIA process among the general community. Further in transport sector projects only highway related projects have been opened for public comments (Bandara, 2001).

Monitoring and evaluation aspects are rarely addressed in the Sri Lankan context. All most all reports just include a section of importance of monitoring and evaluation in general. They do not include a specific plan, time line or parameters that should be monitored. 


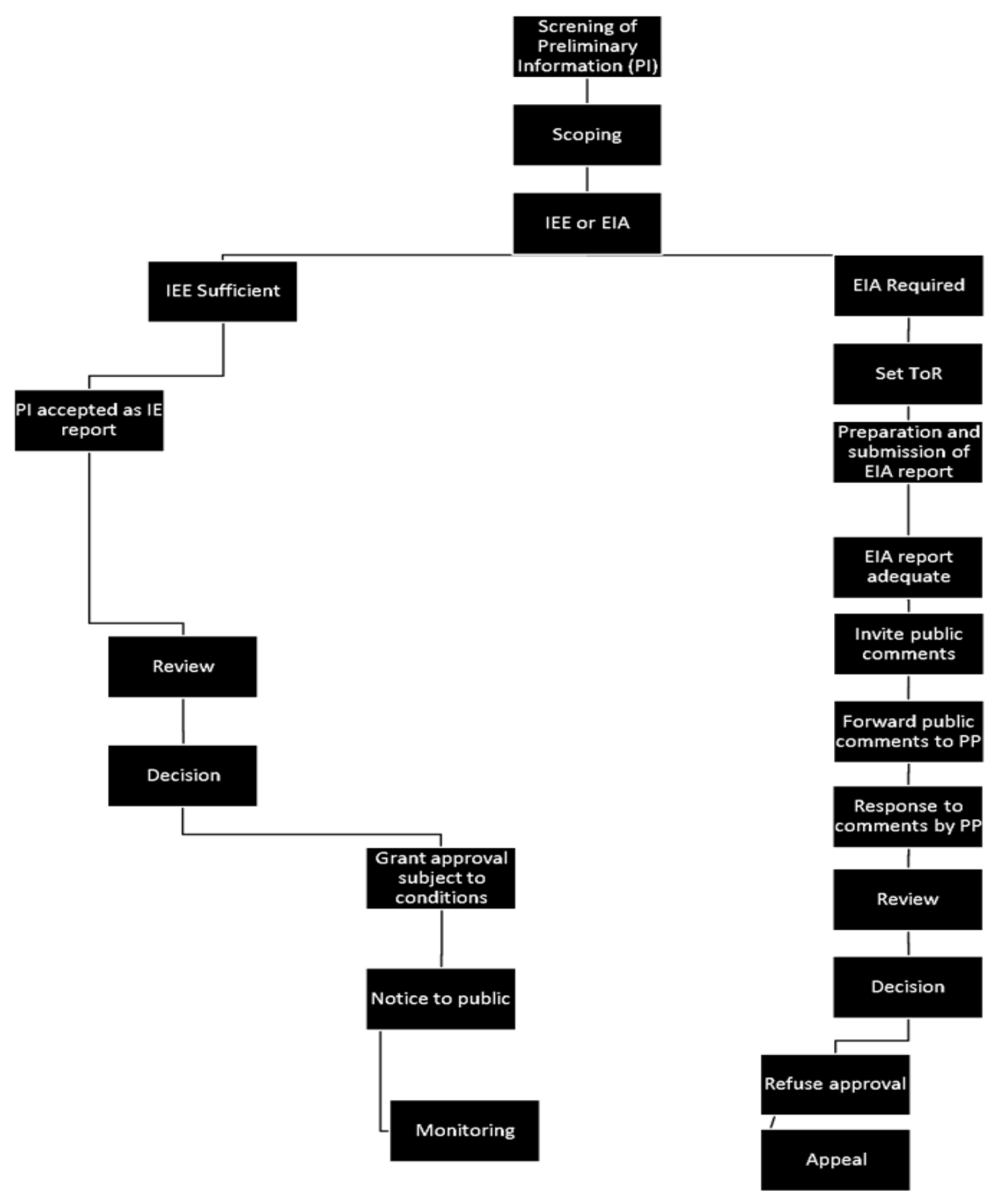

Fig. 1: EIA procedure accordance with National Environmental Act of Sri Lanka. Source: Central Environmental Authority (2006).

Current legislation allows several institutions to act as Project Approving Agencies (PAA). This has caused conflict of interest in several occasions as some of these agencies act as PPs for some projects (e.g. Ministry of Highways and Ministry of Power) (Zubair, 2001) and this has seriously questioned the validity of such EIA reports. 
In addition to all these problems emerges in the EIA process is other decision parameters overrides the findings of the EIA. Financial consideration and political preference precedes environmental considerations and ultimately the EIA report becomes just a document. Considering all these facts the study focused on methods to improve the current practises and the quality of the EIA process and content.

\section{Methodology}

Literature regarding EIA process in both Sri Lankan context and international context was reviewed together with several past EIA reports in Sri Lanka related to civil engineering infrastructure projects (especially transport infrastructure development) to identify the changes in adopted methodologies, format and possible improvements.

EIA reports were reviewed focussing on the following areas.

- Alternatives considered

- Number of alternatives considered

- Whether no option alternative is considered

- Impacts considered

- Identified impact stages of the project

- Potential impacts considered in the study

- Methodology of assessment

- Quantification of impacts (quantitative/ qualitative)

- Weight given to each impact for alternative analysis

- Details of the monitoring programme

Further interviews were held with professionals involved in the EIA process, to identify their views and possible improvements needed in the Sri Lankan EIA context. Interviews focused on the following areas.

- Timing of the EIA process in project life cycle

- Preparation of stakeholder agencies and reviewers

- Evaluating impacts

- Recommendations of the EIA reports

- Legal enforcement and considerations

- Public participation

All these were combined to make recommendations needed for improvement of the current EIA practises.

\section{Results}

Table 1 in this section reviews the content of six transport infrastructure related environmental studies. Table 2 summarises the interviews held with EIA experts in the country. 
Table 1: Methodologies adopted in several EIA/IEEs in Sri Lanka

\begin{tabular}{|c|c|c|c|c|}
\hline Project & $\begin{array}{l}\text { Alternatives } \\
\text { considered }\end{array}$ & $\begin{array}{l}\text { Impacts } \\
\text { considered }\end{array}$ & $\begin{array}{l}\text { Methodology of } \\
\text { assessment }\end{array}$ & Monitoring \\
\hline $\begin{array}{l}\text { Hambantota } \\
\text { Port } \\
\text { (Central } \\
\text { Engineering } \\
\text { Consultancy } \\
\text { Bureau, 2006) }\end{array}$ & $\begin{array}{l}\text { No option } \\
\text { condition is } \\
\text { considered. }\end{array}$ & $\begin{array}{l}\text { Impacts on coastal } \\
\text { environment, } \\
\text { geology, } \\
\text { hydrology, water } \\
\text { and air quality, } \\
\text { noise and } \\
\text { vibration, } \\
\text { ecology, society } \\
\text { have been } \\
\text { identified. } \\
\text { Impacts are } \\
\text { considered on } \\
\text { both construction } \\
\text { and operational } \\
\text { stages. }\end{array}$ & $\begin{array}{l}\text { Only stated the } \\
\text { quantified impacts. }\end{array}$ & $\begin{array}{l}\text { Monitoring } \\
\text { programmes } \\
\text { gives frequency } \\
\text { to monitor and } \\
\text { critical values of } \\
\text { parameters to be } \\
\text { monitored. }\end{array}$ \\
\hline $\begin{array}{l}\text { Matara- } \\
\text { Kataragama } \\
\text { railway } \\
\text { extension } \\
\text { (Department of } \\
\text { Civil } \\
\text { Engineering, } \\
\text { University of } \\
\text { Moratuwa, } \\
\text { 2008) }\end{array}$ & $\begin{array}{l}\text { Six } \\
\text { alternatives } \\
\text { have been } \\
\text { considered. }\end{array}$ & $\begin{array}{l}\text { Impacts on water, } \\
\text { habitats, earth } \\
\text { (soil), } \\
\text { biodiversity, } \\
\text { aesthetics, } \\
\text { hydrology, human } \\
\text { interest, air \& } \\
\text { noise, } \\
\text { transportation, } \\
\text { economic, land } \\
\text { use has been } \\
\text { identified. } \\
\text { Impacts are } \\
\text { considered on } \\
\text { project planning, } \\
\text { construction and } \\
\text { operational stages. }\end{array}$ & $\begin{array}{l}\text { Each impact has } \\
\text { been assigned } \\
\text { weight in EIA. } \\
\text { Quantified impacts } \\
\text { from each category } \\
\text { by alternatives, } \\
\text { and have been } \\
\text { assessed in a } \\
\text { matrix format. } \\
\text { Environmental } \\
\text { cost benefit } \\
\text { analysis has been } \\
\text { performed. }\end{array}$ & $\begin{array}{l}\text { Monitoring } \\
\text { programme } \\
\text { includes } \\
\text { parameters to be } \\
\text { monitored, } \\
\text { frequency of } \\
\text { monitoring, } \\
\text { locations of } \\
\text { monitoring and } \\
\text { responsible } \\
\text { agencies. }\end{array}$ \\
\hline $\begin{array}{l}\text { New Kelani } \\
\text { bridge project } \\
\text { (Oriental } \\
\text { Consultants Co. } \\
\text { Ltd, Katahira \& } \\
\text { Engineers } \\
\text { International, } \\
\text { Consulting } \\
\text { Engineers and } \\
\text { Architects } \\
\text { Associated (Pvt.) } \\
\text { Ltd., 2013) }\end{array}$ & $\begin{array}{l}\text { Four } \\
\text { alternatives } \\
\text { have been } \\
\text { mentioned. } \\
\text { But only the } \\
\text { existing } \\
\text { situation and } \\
\text { the selected } \\
\text { project is } \\
\text { assessed. }\end{array}$ & $\begin{array}{l}\text { Impacts on socio } \\
\text { economic, } \\
\text { landscape, } \\
\text { hydrology, } \\
\text { physio-chemical } \\
\text { environment } \\
\text { (including global } \\
\text { warming), and } \\
\text { ecology has been } \\
\text { considered. }\end{array}$ & $\begin{array}{l}\text { Only stated the } \\
\text { quantified impacts. } \\
\text { Extended cost } \\
\text { benefit analysis } \\
\text { has been } \\
\text { performed. }\end{array}$ & $\begin{array}{l}\text { Monitoring } \\
\text { frequency and } \\
\text { responsible } \\
\text { agency has been } \\
\text { identified. }\end{array}$ \\
\hline
\end{tabular}




\begin{tabular}{|c|c|c|c|c|}
\hline $\begin{array}{l}\text { Northern road } \\
\text { connectivity } \\
\text { project (Road } \\
\text { Development } \\
\text { Authority, 2012) }\end{array}$ & $\begin{array}{l}\text { Existing } \\
\text { condition is } \\
\text { described. }\end{array}$ & $\begin{array}{l}\text { Impacts on water, } \\
\text { habitats, earth } \\
\text { (soil), } \\
\text { biodiversity, } \\
\text { aesthetics, } \\
\text { hydrology, human } \\
\text { interest, air \& } \\
\text { noise, } \\
\text { transportation, } \\
\text { economic, land } \\
\text { use has been } \\
\text { identified. } \\
\text { Impacts are } \\
\text { considered on } \\
\text { preconstruction, } \\
\text { construction and } \\
\text { operational stages. }\end{array}$ & & $\begin{array}{l}\text { No descriptive } \\
\text { monitoring } \\
\text { programme is } \\
\text { given. }\end{array}$ \\
\hline $\begin{array}{l}\text { Outer circular } \\
\text { highway to } \\
\text { Colombo } \\
\text { (Oriental } \\
\text { Consultants } \\
\text { Company LTD, } \\
\text { 2000) }\end{array}$ & $\begin{array}{l}\text { Four } \\
\text { alternatives } \\
\text { been } \\
\text { considered. }\end{array}$ & $\begin{array}{l}\text { Impacts on } \\
\text { hydrology, water } \\
\text { quality, noise and } \\
\text { vibration, air } \\
\text { quality ecology, } \\
\text { society, economy } \\
\text { have been } \\
\text { identified. }\end{array}$ & $\begin{array}{l}\text { Alternatives are } \\
\text { compared in } \\
\text { matrix format } \\
\text { considering urban, } \\
\text { social and } \\
\text { economic } \\
\text { sustainability, cost } \\
\text { factors and } \\
\text { resettlement } \\
\text { effects. Qualitative } \\
\text { and quantitative } \\
\text { methods have been } \\
\text { used. } \\
\text { Environmental } \\
\text { cost benefit } \\
\text { analysis has been } \\
\text { performed. }\end{array}$ & $\begin{array}{l}\text { Discuss } \\
\text { institutional } \\
\text { requirements for } \\
\text { monitoring and } \\
\text { frequency of } \\
\text { monitoring. }\end{array}$ \\
\hline $\begin{array}{l}\text { Southern } \\
\text { transport } \\
\text { development } \\
\text { project } \\
\text { (Road } \\
\text { Development } \\
\text { Authority, } \\
\text { 2007) }\end{array}$ & - & $\begin{array}{l}\text { Impacts on } \\
\text { hydrology, water } \\
\text { quality, sediment } \\
\text { quality, air } \\
\text { quality, } \\
\text { noise/ground } \\
\text { vibration, society, } \\
\text { natural } \\
\text { environment, } \\
\text { earth (soil) and } \\
\text { transport has been } \\
\text { identified. }\end{array}$ & - & $\begin{array}{l}\text { Parameters to be } \\
\text { monitored, } \\
\text { monitoring } \\
\text { locations, } \\
\text { frequency and } \\
\text { responsible } \\
\text { agency has been } \\
\text { identified }\end{array}$ \\
\hline
\end{tabular}


Table 2: Problems identified from the interviews

\begin{tabular}{|c|c|}
\hline Focus area & Problems \\
\hline $\begin{array}{l}\text { Timing of the EIA process } \\
\text { in project life cycle }\end{array}$ & $\begin{array}{l}\text { Since the timing of the EIA process has not been clearly } \\
\text { defined in legislature, EIA process is usually conducted after } \\
\text { the selection of alternatives; where environmental impacts } \\
\text { are not thoroughly considered. }\end{array}$ \\
\hline $\begin{array}{l}\text { Preparation of stakeholder } \\
\text { agencies and reviewers }\end{array}$ & $\begin{array}{l}\text { Lack of expertise in the EIA process among stakeholder } \\
\text { agencies such as local authorities, have created problems in } \\
\text { the scoping stage. During scoping stage proper boundaries } \\
\text { for the EIA evaluation is not clearly demarcated and that has } \\
\text { created problems in the later stage of the evaluation process. } \\
\text { Further poor understanding of the EIA process among the } \\
\text { reviewers from different agencies have caused negative } \\
\text { impact on the whole evaluation process }\end{array}$ \\
\hline Evaluating impacts & $\begin{array}{l}\text { Though there are several guidelines for the EIA process, no } \\
\text { guidelines are given for evaluation or the content of the EIA } \\
\text { report. Hence most of the time EIA reports just represent a } \\
\text { list of identified possible impacts, not their magnitude and } \\
\text { the extent. Further these impacts mainly focus on narrow, } \\
\text { short term and immediate impacts of individual project. The } \\
\text { trend of identify only the impacts, not their magnitude has } \\
\text { led to preparation of generic EIA reports rather than site } \\
\text { specific evaluation reports. }\end{array}$ \\
\hline $\begin{array}{l}\text { Recommendations of the } \\
\text { EIA reports }\end{array}$ & $\begin{array}{l}\text { None identifying of the magnitude has created problems in } \\
\text { proposing suitable and necessary migratory measures. } \\
\text { Therefore most of the reports lack Environmental } \\
\text { Management Plan (EMP) and specific recommendation to } \\
\text { the project }\end{array}$ \\
\hline $\begin{array}{l}\text { Legal enforcement and } \\
\text { considerations }\end{array}$ & $\begin{array}{l}\text { Although new regulations have come up regarding water } \\
\text { pollution and sound pollution and other physical parameters } \\
\text { in Sri Lanka, this is still true for ecological, social impacts } \\
\text { and resettlement. }\end{array}$ \\
\hline Public participation & $\begin{array}{l}\text { Public participation has occurred significant only on } \\
\text { occasion where Non-Governmental Organizations (NGO) } \\
\text { took an interest of the project }\end{array}$ \\
\hline
\end{tabular}

\section{Discussion}

Considering unreasonable alternatives, or neglecting alternatives (Table 1 shows evaluations considering only one option) and being biased to a predetermined alternative are among usual cases because EIA process usually happens after the pre-feasibility stage (as shown in the $1^{\text {st }}$ row of Table 2 ), where various alternatives are considered and decisions are made. In that stage, usually only financial considerations are given proper attention and that could lead to selection of an alternative having considerable negative environmental impacts where more viable options are available. Adopting proper policies for timing for EIA and propper techniques for generating alternatives process will address this issue. Examples can be seen in route planning in Channel Tunnel high speed rail link in UK (Goodenough \& Page, 1994). 
Most of the time the PPs try to bypass the EIA process as they see this process has a hindrance (both costly and time consuming) and just as legal requirement for the project (Zubair, 2001). They do not understand the benefits that could be achieved through this assessment for themselves and the society or the region as a whole. So informing the PPs about the possible economic and other benefits that they could achieve by properly conducting the EIA and taking necessary migratory measures will drive them to conduct EIA more rigorously.

Lack of expertise in the EIA process has being a hindrance to the effectiveness of the EIA from its inception, in developing countries (Jay et al., 2007). According to the interview (as shown in $2^{\text {nd }}$ row of Table 2) with the officials, though training has been given to some groups, problem occurs as they do not remain in the same institution. This is due to the institution set up in public sector in Sri Lanka. Ultimately this leaves the project approving agencies with untrained professionals for evaluation. Therefore an institution independent from typical government set up could be established to address this issue as in the case of Netherlands (De Silva, Pers. Comm.). Further this will address the issue of conflict of interest, faced by several PAAs (Zubair, 2001).

According to both Table 1 and Table 2, it can be seen that quantifying impact is a major issue. Various methods can be found in literature that can be used to address this issue (Pastakia \& Jensen, 1998; Bonachea, et al., 2005). However, even when impacts are quantified ( 3 cases in Table 1) they are mainly quantified based on the magnitude of the impact only. This may lead to assigning high priority to large scale short term impact/s which could not be so critical in the long run. Therefore when quantifying the impacts, multiplication of the magnitude and the duration of the impact should be considered.

In impact assessment, proper attention should be given to the impacts to climate change and resource degradation that are caused by the proposed development. Greenhouse gas emission is caused not only by the fossil fuel combustion but by land use changes also (Karl $\&$ Trenbirth, 2003). Therefore it is at great importance to quantify such impacts (Bristow \& Nellthorp, 2000; Pielke-Sr, et al., 2002; Fuglestvedt, et al., 2010; Uherek, et al., 2010). Row 3 of Table 1 presents a local example for the New Kelani Bridge. Further, alternatives could be evaluated based on the resilience to these impacts and the possible increase of mitigation and adaptation capabilities of communities. These aspects should be given proper attention specially in transport development projects as this sector contributes considerable fraction of greenhouse gas emissions (Chapman, 2007).

Proper legal framework should be established to address the issues regarding ecological (Geneletti, 2003) and social protection. Lessons can be learnt from developed countries such as Netherlands and United States where they have successfully implemented such system (Swell, 1996).Further, legal framework should be improved to include the content of the EIA report (De Silva, Pers. Comm.). This is to avoid the misuse of such absence and not including quantified impacts, migratory methods and follow up programmes with specific objectives and time lines. Further these improvements should address the conflict of interest of certain PAAs.

In addition to the project based EIA process, Strategic Environmental Assessment (SEA) can be practised to overcome the inherent weaknesses of the reactive nature of EIA and to direct development in the right direction, by considering cumulative effects (Cooper \& Sheate, 2002). However, proper coordination among various development agencies and local authorities is essential in this matter, as Sri Lanka is failing in this attempt due to the same fact (De Silva, Pers. Comm.). 


\section{Conclusions}

Based on the review of Sri Lankan EIA reports following steps can be made to improve the EIA process. Establishment of proper guidelines are essential for the stages (at which phase of project design) which the EIA practises should be adopted. Quantification of the impacts should be based on the multiplication of the magnitude and the duration of impact and also impacts quantification should be done on climate change and resource degradation.

Moreover, alternatives should be evaluated based on the resilience to climate impacts and the possible increase of the mitigation and adaptation as a society and assigning a proper weight to environmental impacts in alternative analysis in feasibility and EIA activities is also essential.

Based on results from interviews held, establishment of an independent institution for project approving following measures and improvement of the legal framework for better social and ecological protection and to ensure detail monitoring and evaluation process can be suggested as improvements.

\section{Acknowledgement}

Authors acknowledge the support of Prof (Mrs) Nilanthi Bandara, Mrs. Kanthi De Silva (Director EIA of Central Environmental authority) and Mr. H.M.K.G.G. Bandara (Director Planning Road development Authority) in this study.

\section{References}

Bandara, J., 2000. Issues related to transport sector environmental impact assessments (EIA): Experience in Sri Lanka. Proceedings of the Seventh Annual Forestry and Environmental Symposium 2001 of the Department of Forestry and Environmental Science University of Sri Jayewardenepura, Sri Lanka, p.40.

Bonachea, J., Bruschi, V. M., Remondo, J., González-Díez, A., Salas, L., Bertens, J., Aramburu, J. M., 2005. An approach for quantifying geomorphological impacts for EIA of transportation infrastructures: a case study in northern Spain. Geomorphology, 66:95-117.

Bristow, A., Nellthorp, J., 2000. Transport project appraisal in the European Union. Transport Policy, 7:51-60.

Caron, C. M., 2003. Defining the Public Interest, Negotiating Rights: The Influence of Environmental Impact Assessment Legislation in Sri Lanka. 9th International Conference on Sri Lanka Studies. Matara.

Central Engineering Consultancy Bureau, 2006. Environmental impact assessment of the proposed Hambanthota port project. Draft final Report.

Central Environmental Authority, 1998. Simple questions and answers on Environmental Impact Assessment (EIA). Central Environmental Authority.

Central Environmental Authority, 2009. Environmental protection Licence. Central Environmental Authority.

Central Environmental Authority, 2006. Guidance for implementing the Environmental Impact Assessment (EIA) Process; No: 1 A general guide for Project Approving Agencies (PAA) (4th ed.). Central Environmental Authority.

Central Environmental Authority, 2006. Guidance for implementing the Environmental Impact Assessment (EIA) Process; No: 2 A general guide for conducting environmental scoping (3rd ed.). Central Environmental Authority. 
Chapman, L., 2007. Transport and climate change: a review. Journal of Transport Geography, 15:354-367.

Commission of the European Communities, 1985. Council directive of 27 June 1985 on the assessment of effects of certain public and private projects on the environment. Official Journal of the European Communities, L175:40-48.

Cooper, L., Sheate, W., 2002. Cumulative effects assessment: A review of UK environmental impact statements. Environmental Impact Assessment Review, 22:415-439.

De Silva, K. Personnel Communication. Director EIA, Central Environmental Authority, Sri Lanka.

Department of Civil Engineering, University of Moratuwa, 2008. Environmental Impact Assessment- Matara Kataragama Railway Extension.

Folkeson, L., Antonson, H., Heedin, J., 2013. Planners' views on cumulative effects. A focus group study concerning transport infrastructure planning in Sweden. Land Use Policy, 30:243-253.

Fuglestvedt, J., Shine, K., Berntsen, T., Cook, J., Lee, D., Stenke, A., Waitz, I., 2010. Transport impacts on atmosphere and climate: Metrics. Atmospheric Environment. 44:4648-4677.

Geneletti, D., 2003. Biodiversity Impact Assessment of roads: an approach based on ecosystem rarity. Environmental Impact Assessment Review, 23:343-365.

Goodenough, R.A., Page, S.J., 1994. Evaluating the environmental impact of a major transport infrastructure project: the Channel Tunnel high-speed rail link. Applied Geography, 14:26-50.

Jay, S., Jones, C., Slinn, P., Wood, C., 2007. Environmental impact assessment: Retrospect and prospect. Environmental Impact Assessment Review. 27:287-300.

Jayawardana, D., 2012. Sethusamudram and its impact on Sri Lanka. http://www. dailymirror.lk/business/features/18501-sethusamudram-and-its-impact-on-sri-lanka. html. Accessed September 27, 2013.

Kannangara, N., 2013. Mattala International Airport in Mid-air Battle. http://www. thesundayleader.lk/2013/03/31/mattala-international-airport-in-mid-air-battle/. Accessed on December 9, 2013,

Karl, T., Trenbirth, K., 2003. Modern global climate change. Science, 302:1719-1723.

Lee , N., George, C., 2000. Environmental assessment in developing and transitional countries. Wiley, Chiichester.

Lee, N., 1983. Environmental impact assessment: a review. Applied Geography. 3(1):5-27.

Oriental Consultants Company LTD., 2000. The Study on the Outer Circular Highway to the City of Colombo; Volume 5 Environmental and social impact assessment.

Oriental Consultants Co. Ltd, 2013. Proposed The Second New Kelani Bridge Project: Environmental Impact Assessment.

Pastakia, C., Jensen, A., 1998. The rapid impact assessment matrix (Riam) for EIA. Environmental Impact Assessment Review, 18:461-482.

Pielke-Sr, R., Marland, G., Betts, R., Chase, T. N., Eastman, J., Niles, J., Running, S., 2002. The influence of land-use change and landscape dynamics on the climate system: relevance to climate-change policy beyond the radiative effect of greenhouse gases. The Royal Society, 1705-1719.

Roads Development Authority, 2007. Environmental Management Plan for Southern Transport Development Project.

Roads Development Authority, 2012. Initial Environmental Examination, Sri Lanka: Northern Road Connectivity Project: Additional Financing. 
Swell, C. G., 1996. Conflicting benefits: National implementation of the United Nations Framework Convention on Climate Change. Environmental Impact Assessment Review, 16:137-150.

Uherek, E., Halenka, T., Borken-Kleefeld, J., Balkanski, Y., Berntsen, T., Borrego, C., Schmid, S., 2010. Transport impacts on atmosphere and climate: Land transport. Atmospheric Environment, 44:4772-4816.

Wijesekara, N., 1999. Present day needs in Environmental Impact Assessment Evaluation The UKHP of Sri Lanka, an example of the challenge. Proceedings of the First Annual South Asian Environmental Assessment. Kathmandu, Nepal: the World Conservation Union, pp.130-145.

Zubair, L., 2001. Challenges for environmental impact assessment in Sri Lanka. Environmental Impact Assessment Review. 21:469-478. 